\begin{tabular}{l|l|l} 
jurnal & Jurnal Kependidikan Dasar & Volume 6 \\
Nomor 2 \\
Theriez & Islam Berbasis Sains & Tahun 2021 \\
\hline
\end{tabular}

\title{
PENGARUH APLIKASI MARBEL MEMBACA TERHADAP KEMAMPUAN MEMBACA ANAK DISLEKSIA
}

\author{
Shahnaz Surayya ${ }^{1}$, Husni Mubarok ${ }^{2}$ \\ 1,2Universitas Islam Nahdlatul Ulama Jepara \\ Surel: shanazsasa17@gmail.com
}

\begin{abstract}
Abstrak
Pembelajaran untuk anak disleksia harus lebih menekankan pada proses belajar dimana anak disleksia dapat mengatasi kesulitan membaca, menulis atau mengeja. Namun dalam kenyataan masih banyak sekali anak disleksia yang tidak mendapat perhatian intens dalam memudahkan anak tersebut dapat membaca. Karena ketidakmampuan membaca dan menghafal abjad maka anak disleksia akan sangat tertinggal dibanding dengan anak di usianya. Berdasarkan masalah tersebut maka diperlukan adanya penelitian dengan metode eksperimen menggunakan aplikasi pembelajaran yang dapat membantu anak disleksia hafal abjad. Tujuan dari penelitian yaitu anak disleksia dapat menghafal abjad dengan baik menggunakan bantuan aplikasi Marbel Membaca. Langkah-langkah yang dilakukan oleh peneliti yaitu menentukan bahan, alat dan strateginya, menentukan tujuan penelitian, mempersiapkan kebutuhan peralatan dan sarana yang dibutuhkan dan melakukan uji eksperimen. Untuk teknik pengumpulan datanya menggunakan observasi, dokumen dan wawancara dengan bantuan angket. Lalu penelitian diukur dengan angket respon anak disleksia yang direkap menggunakan skala likert untuk mengetahui persentase pengaruh aplikasi Marbel Membaca untuk anak disleksia kemudian menggunakan rating scale untuk menafsirkan besar pengaruh aplikasi Marbel Membaca untuk anak disleksia. Berdasarkan rekap respon anak disleksia mendapat $90 \%$ atau dikategorikan anak disleksia sangat suka dan terjadi perubahan untuk hafal membaca abjad anak disleksia. Dengan demikian maka aplikasi Marbel Membaca dapat layak diterapkan dalam pembelajaran membaca untuk anak disleksia.
\end{abstract}

Kata Kunci: aplikasi, membaca, disleksia

\begin{abstract}
Learning for dyslexic children should emphasize more on the learning process where dyslexic children can overcome difficulties in reading, writing or spelling. However, in reality there are still many dyslexic children who do not receive intense attention in making iteasier for them to read. Because of the inability to read and memorize the alphabet, dyslexic children will be left behind compared to children their age. Based on these problems, it is necessary to research with experimental methods using learning applications that can help dyslexic children memorize the alphabet. The purpose of the research is that dyslexic children can memorize the alphabet well using the help of the Marbel Reading application. The steps taken by the researcher are determining the materials, tools
\end{abstract}


and strategies, determining the research objectives, preparing the equipment and facilities needed and conducting experimental tests. For data collection techniques using observation, documents and interviews with the help of a questionnaire. Then the study was measured by a questionnaire response of dyslexic children which was recapitulated using a Likert scale to determine the percentage effect of the Marbel Reading application for dyslexic children and then using a rating scale to interpret the effect of the Marbel Reading application for dyslexic children. Based on the recap of responses, dyslexic children got $90 \%$ or categorized as dyslexic children really like it and there was a change in memorizing the alphabet of dyslexic children. Thus, the Marbel Reading application can be feasible to be applied in learning to read for dyslexic children.

Keywords : application, reading, dyslexia

\section{A. PENDAHULUAN}

Sebuah rahasia umum apabila terdapat anak yang terlihat berbeda dibanding dengan anak lain yang seusianya akan dikatakan abnormal, namun ternyata tidak semua anak yang berbeda itu adalah anak abnormal. Salah satunya adalah anak berkebutuhan khusus tipe disleksia. Anak disleksia penampilan dan IQ nya normal, akan tetapi memerlukan stimulus yang berbeda dengan anak reguler, karena anak yang mengidap penyakit disleksia terjadi karena adanya gangguan pada syaraf batang otak, dan disitulah syaraf bahasa yang diserang. Dengan demikian, faktor yang dapat ditimbulkan pada anak disleksia usia sekolah seperti halnya kemampuan membacanya yang sangat rendah dibanding dengan anak reguler lainnya, lalu pasti akan mengalami kesulitan dalam mengeja, membedakan kata, serta selalu menghindari kegiatan membaca. Anak dengan tipe disleksia menganggap bahwa pelajaran membaca adalah pelajaran yang sangat menakutkan dan menyebalkan. Akibat yang akan ditimbulkan tentu pembelajaran anak disleksia sangat terhambat dan tertinggal dibandingkan anak lainnya dengan usia yang sama. Padahal dasar memahami materi dan segala hal adalah membaca.

Pengertian dari membaca merupakan kegiatan menangkap yang tersirat dari bahan yang tersurat. Kesanggupan seseorang dalam membaca atau menangkap amanat yang tersirat dari bahan yang tersurat serta mengarahkan pada lambang-lambang tertulis dengan lafal dan nada yang tepat tidak sama atau berbeda-beda satu sama lainnya. Pengertian membaca menurut Rahman \& Haryanto yaitu proses interaksi antara pembaca dengan bahan bacaan. Pembaca yang baik harus dapat mengenali unsur-unsur bacaan (huruf, suku kata dan kalimat) lalu melafalkan serta memahami maknanya. ${ }^{1}$ Dari kalimat tersebut dijelaskan bahwa dengan membaca kita dapat mengangkap dan memahami arti serta maksud dari tulisan yang kita baca. Akan tetapi untuk anak tipe disleksia dia tidak dapat membaca dan membedakan huruf, sehingga anak dengan disleksia tidak mampu membaca kemudian mencerna maksud dari tulisan yang dia lihat.

\footnotetext{
${ }^{1}$ Budi Rahaman dan Haryanto, "Peninkatan Ketrampilan Membaca Permulaan melalui Media Flashcard pada Siswa Kelas 1 SDN Bajayau Tengah 2,” Jurnal Prima Edukasia 2, No. 2 (2014): 127-37.
} 
Pengertian disleksia adalah suatu gangguan proses belajar dimana seseorang mengalami kesulitan membaca, menulis atau mengeja. ${ }^{2}$ Karakteristik anak disleksia adalah: 1) kesulitan mengenali huruf dan mengejanya, 2) kesulitan membuat pekerjaan tertulis secara terstruktur, 3) huruf tertukar misal 'b' dengan 'd' lalu 'p' dengan ' $q$ ' lalu 'm dengan ' $w$ ' dan 's' dengan ' $z$ ', 4) membaca lambat, terputus-putus dan tidak tepat . ${ }^{3}$

Kemampuan dasar dari anak sekolah adalah dapat membedakan dan menghafal abjad sehingga saat abjad-abjad yang digabung dapat menjadi sebuah kata bahkan kalimat yang memiliki makna, maka orang yang membaca akan tau dan paham maksud yang dituju oleh penulis bacaan. Namun, untuk anak disleksia, ia tidak bisa hafal bahkan tidak bisa membedakan abjad yang serupa tersebut. Sudah seharusnya menjadi perhatian bersama terhadap kesulitan yang dialami oleh anak tipe disleksia yang ada disekitar kita.

Dalam Peraturan Pemerintah No. 17 Tahun 2010 Pasal 129 ayat 3 yang menerangkan bahwa pendidikan anak disleksia harus sesuai dengan kebutuhan mereka, sehingga hasilnya anak disleksia dapat secara mandiri untuk mengatasi apa yang pernah menjadi kendalanya. Anak tipe disleksia apabila tidak mendapatkan perhatian dari ahli atau lingkungan sekitar maka akan menuju pada kelainan. Padahal anak tipe disleksia tidak abnormal, IQ nya pun normal, hanya saja anak tipe disleksia membutuhkan pendidikan yang lebih supaya hasilnya akan menjadi anak yang tumbuh menjadi pribadi mandiri dan dapat mengikuti aktivitas seperti teman-teman seusianya.

Persoalan-persoalan tentang anak berkebutuhan khusus tipe disleksia yang membutuhkan pendidikan lebih. Maka dari itu, dalam penelitian ini membuat peneliti tergerak melakukan sebuah penelitian dengan anak berkebutuhan khusus tipe disleksia. Langkah pertama yang dilakukan oleh peneliti adalah melakukan pencarian mengenai anak disleksia. Lokasi pencarian di Desa Bangsri Kecamatan Bangsri. Setelah mendapatkan data terakait anak disleksia. Langkah yang kedua, peneliti lalu berkunjung ke rumahnya untuk mencari informasi dari orang tua yang memiliki anak disleksia. Langkah ketiga, peneliti melakukan observasi secara langsung kepada anak disleksia tersebut.

Hasil observasi pada salah satu anak berusia 12 Tahun Kelas 6 SD yang berkebutuhan khusus tipe disleksia didapatkan hasil yaitu anak tersebut belum dapat hafal abjad serta belum dapat menulis kata dengan mandiri. Dengan demikian maka peneliti tertarik untuk melakukan penelitian dengan tujuan untuk menumbuhkan kemampuan membaca khususnya hafal abjad a sampai dengan z dengan menggunakan aplikasi Marbel Membaca. Karena anak-anak lebih suka bermain game dengan android, maka dari itulah peneliti memanfaatkan media digital dalam pembelajaran yaitu dengan menerapkan pembelajaran dengan anak tipe disleksia berbantu aplikasi yang seru, menyenangkan, dan membawa dampak manfaat yang luar biasa.

\footnotetext{
${ }^{2}$ Irdamurni et al., "Meningkatkan Kemampuan Guru pada Pembelajaran Membaca Anak Dislesksia," Jurnal Pendidikan Kebutuhan Khusus 2, no. 2 (2018): 29-40.

${ }^{3}$ N. H. Rofiah, "Proses Indentifikasi: 'Mengenal Anak Kesulitan Belajar Tipe Disleksia bagi Guru Sekolah Dasar Inklusi'.,” Jurnal Inklusi 2, no. 1 (2015): 109-124.
} 
Aplikasi membuat proses pembelajaran lebih menarik dengan gambar-gambar ilustrasi cerita, suara dan teks dapat terintegrasi dan dapat dikendalikan sesuai keinginan, membuat siswa lebih senang untuk belajar sambil bermain dan lebih mudah dicerna materinya. 4

Penelitian ini juga relevan dengan penelitian yang telah dilakukan oleh Abidin, Marzal, \& Rohati dalam penelitiannya yang berjudul "Pengembangan Media Pembelajaran Matematika Interaktif Berbasis Android untuk Menumbuhkan Motivasi Belajar Anak Disleksia pada Materi Eksponensial di Kota Jambi". Hasil penelitiannya menyatakan bahwa persentase nilai p yang diperoleh berdasarkan indikator sebesar 84,58\% kategori baik dalam skala interpretasi, lalu untuk pernyataan favourable nilai p mencapai 93,33\% lalu untuk pernyataan unfavourable nilai p mencapai 77,5\%. Dan saat pembelajaran pun siswa lebih banyak bertanya, berani mengungkapkan pendapat, serta tidak mudah menyerah saat berhadapan dengan soal yang lebih sulit. Dan siswa disleksia menjadi mudah dalam memahami pembelajaran karena tidak kesulitan membaca dan melihat huruf serta angka. ${ }^{5}$

Didukung juga dengan penelitian lain yang dilakukan oleh Moraza \& Nurhastuti Tahun 2021 dalam penelitiannya yang berjudul "Mengurangi Kesalahan Membaca Permulaan Pada Anak Disleksia (X) Melalui Media Pembelajaran Berbasis Aplikasi Game Secil". Hasil penelitiannya menyatakan bahwa terjadi peningkatan kemudian stabil dengan presentase skor yang baik. Dengan pembelajaran menggunakan aplikai game secil kesalahan anak dalam membaca pada kemampuan membaca kelompok kata dengan konsonan rangkap "ng" dan "ny" berkurang. 6

Berdasarkan uraian tersebut maka untuk memberi solusi terhadap permasalahan kemampuan membaca anak disleksia, peneliti juga menggunakan aplikasi pembelajaran yang berjudul Marbel Membaca dengan maksud supaya peserta didik disleksia mendapat peningkatan dalam membacanya. Dari latar belakang tersebut maka peneliti akan mengkaji penelitian tentang " Pengaruh Aplikasi Marbel Membaca Terhadap Kemampuan Membaca Anak Disleksia".

\section{B. PENDAHULUAN}

Sebuah rahasia umum apabila terdapat anak yang terlihat berbeda dibanding dengan anak lain yang seusianya akan dikatakan abnormal, namun ternyata tidak semua anak yang berbeda itu adalah anak abnormal. Salah satunya adalah anak berkebutuhan khusus tipe disleksia. Anak disleksia penampilan dan IQ nya normal, akan tetapi memerlukan stimulus yang berbeda dengan anak reguler, karena anak yang mengidap

${ }^{4}$ R. Y Arindino dan N. Ramadhani, "Perancangan Media Pembelajaran Interaktif Matematika untuk Siswa Kelas 6 SD," Jurnal Sains dan Seni Pomits 2, No. 1 (2013): 28-32.

${ }^{5}$ Marzal Abidin and Rohati J., "Pengembangan Media Pembelajaran Matematika Interaktif Berbasis Android untuk Menumbuhkan Motivasi Belajar Anak Disleksia pada Materi Eksponensial Di Kota Jambi," Jurnal Edumatica 4, No. 2 (2014): 66-76.

${ }^{6}$ A Moraza dan Nurhastuti, "Mengurangi Kesalahan Membaca Permulaan pada Anak Disleksia (X) melalui Media Pembelajaran berbasis Aplikasi Game Secil," Juppekhu: Jurnal Penelitian Pendidikan Khusus 9, no. 1 (2021): 35-43. 
penyakit disleksia terjadi karena adanya gangguan pada syaraf batang otak, dan disitulah syaraf bahasa yang diserang. Dengan demikian, faktor yang dapat ditimbulkan pada anak disleksia usia sekolah seperti halnya kemampuan membacanya yang sangat rendah dibanding dengan anak reguler lainnya, lalu pasti akan mengalami kesulitan dalam mengeja, membedakan kata, serta selalu menghindari kegiatan membaca. Anak dengan tipe disleksia menganggap bahwa pelajaran membaca adalah pelajaran yang sangat menakutkan dan menyebalkan. Akibat yang akan ditimbulkan tentu pembelajaran anak disleksia sangat terhambat dan tertinggal dibandingkan anak lainnya dengan usia yang sama. Padahal dasar memahami materi dan segala hal adalah membaca.

Pengertian dari membaca merupakan kegiatan menangkap yang tersirat dari bahan yang tersurat. Kesanggupan seseorang dalam membaca atau menangkap amanat yang tersirat dari bahan yang tersurat serta mengarahkan pada lambang-lambang tertulis dengan lafal dan nada yang tepat tidak sama atau berbeda-beda satu sama lainnya. Pengertian membaca menurut Rahman \& Haryanto yaitu proses interaksi antara pembaca dengan bahan bacaan. Pembaca yang baik harus dapat mengenali unsur-unsur bacaan (huruf, suku kata dan kalimat) lalu melafalkan serta memahami maknanya. ${ }^{7}$ Dari kalimat tersebut dijelaskan bahwa dengan membaca kita dapat mengangkap dan memahami arti serta maksud dari tulisan yang kita baca. Akan tetapi untuk anak tipe disleksia dia tidak dapat membaca dan emmbedakan huruf, sehingga anak dengan disleksia tidak mampu membaca kemudian mencerna maksud dari tulisan yang dia lihat.

Pengertian disleksia adalah suatu gangguan proses belajar dimana seseorang mengalami kesulitan membaca, menulis atau mengeja. ${ }^{8}$ Karakteristik anak disleksia adalah: 1) kesulitan mengenali huruf dan mengejanya, 2) kesulitan membuat pekerjaan tertulis secara terstruktur, 3) huruf tertukar misal 'b' dengan 'd' lalu 'p' dengan ' $q$ ' lalu 'm dengan 'w' dan 's' dengan ' $z$ ', 4) membaca lambat, terputus-putus dan tidak tepat. ${ }^{9}$

Kemampuan dasar dari anak sekolah adalah dapat membedakan dan menghafal abjad sehingga saat abjad-abjad yang digabung dapat menjadi sebuah kata bahkan kalimat yang memiliki makna, maka orang yang membaca akan tau dan paham maksud yang dituju oleh penulis bacaan. Namun, untuk anak disleksia, ia tidak bisa hafal bahkan tidak bisa membedakan abjad yang serupa tersebut. Sudah seharusnya menjadi perhatian bersama terhadap kesulitan yang dialami oleh anak tipe disleksia yang ada disekitar kita.

Dalam Peraturan Pemerintah No. 17 Tahun 2010 Pasal 129 ayat 3 yang menerangkan bahwa pendidikan anak disleksia harus sesuai dengan kebutuhan mereka, sehingga hasilnya anak disleksia dapat secara mandiri untuk mengatasi apa yang pernah menjadi kendalanya. Anak tipe disleksia apabila tidak mendapatkan perhatian dari ahli atau lingkungan sekitar maka akan menuju pada kelainan. Padahal anak tipe disleksia tidak

\footnotetext{
${ }^{7}$ Budi Rahaman dan Haryanto, "Peninkatan Ketrampilan Membaca Permulaan melalui Media Flashcard pada Siswa Kelas 1 SDN Bajayau Tengah 2,” Jurnal Prima Edukasia 2, No. 2 (2014): 127-37.

${ }^{8}$ Irdamurni et al., "Meningkatkan Kemampuan Guru pada Pembelajaran Membaca Anak Dislesksia," Jurnal Pendidikan Kebutuhan Khusus 2, No. 2 (2018): 29-40.

${ }^{9}$ N. H. Rofiah, "Proses Indentifikasi: 'Mengenal Anak Kesulitan Belajar Tipe Disleksia bagi Guru Sekolah Dasar Inklusi'.," Jurnal Inklusi 2, No. 1 (2015): 109-124.
} 
abnormal, IQ nya pun normal, hanya saja anak tipe disleksia membutuhkan pendidikan yang lebih supaya hasilnya akan menjadi anak yang tumbuh menjadi pribadi mandiri dan dapat mengikuti aktivitas seperti teman-teman seusianya.

Persoalan-persoalan tentang anak berkebutuhan khusus tipe disleksia yang membutuhkan pendidikan lebih. Maka dari itu, dalam penelitian ini membuat peneliti tergerak melakukan sebuah penelitian dengan anak berkebutuhan khusus tipe disleksia. Langkah pertama yang dilakukan oleh peneliti adalah melakukan pencarian mengenai anak disleksia. Lokasi pencarian di Desa Bangsri Kecamatan Bangsri. Setelah mendapatkan data terakait anak disleksia. Langkah yang kedua, peneliti lalu berkunjung ke rumahnya untuk mencari informasi dari orang tua yang memiliki anak disleksia. Langkah ketiga, peneliti melakukan observasi secara langsung kepada anak disleksia tersebut.

Hasil observasi pada salah satu anak berusia 12 Tahun Kelas 6 SD yang berkebutuhan khusus tipe disleksia didapatkan hasil yaitu anak tersebut belum dapat hafal abjad serta belum dapat menulis kata dengan mandiri. Dengan demikian maka peneliti tertarik untuk melakukan penelitian dengan tujuan untuk menumbuhkan kemampuan membaca khususnya hafal abjad a sampai dengan $\mathrm{z}$ dengan menggunakan aplikasi Marbel Membaca. Karena anak-anak lebih suka bermain game dengan android, maka dari itulah peneliti memanfaatkan media digital dalam pembelajaran yaitu dengan menerapkan pembelajaran dengan anak tipe disleksia berbantu aplikasi yang seru, menyenangkan, dan membawa dampak manfaat yang luar biasa.

Aplikasi membuat proses pembelajaran lebih menarik dengan gambar-gambar ilustrasi cerita, suara dan teks dapat terintegrasi dan dapat dikendalikan sesuai keinginan, membuat siswa lebih senang untuk belajar sambil bermain dan lebih mudah dicerna materinya. ${ }^{10}$

Penelitian ini juga relevan dengan penelitian yang telah dilakukan oleh Abidin, Marzal, \& Rohati dalam penelitiannya yang berjudul "Pengembangan Media Pembelajaran Matematika Interaktif Berbasis Android untuk Menumbuhkan Motivasi Belajar Anak Disleksia pada Materi Eksponensial di Kota Jambi". Hasil penelitiannya menyatakan bahwa persentase nilai p yang diperoleh berdasarkan indikator sebesar 84,58\% kategori baik dalam skala interpretasi, lalu untuk pernyataan favourable nilai p mencapai 93,33\% lalu untuk pernyataan unfavourable nilai p mencapai 77,5 \%. Dan saat pembelajaran pun siswa lebih banyak bertanya, berani mengungkapkan pendapat, serta tidak mudah menyerah saat berhadapan dengan soal yang lebih sulit. Dan siswa disleksia menjadi mudah dalam memahami pembelajaran karena tidak kesulitan membaca dan melihat huruf serta angka. ${ }^{11}$

Didukung juga dengan penelitian lain yang dilakukan oleh Moraza \& Nurhastuti Tahun 2021 dalam penelitiannya yang berjudul "Mengurangi Kesalahan Membaca Permulaan Pada Anak Disleksia (X) Melalui Media Pembelajaran Berbasis Aplikasi Game

${ }^{10}$ R. Y Arindino dan N. Ramadhani, "Perancangan Media Pembelajaran Interaktif Matematika untuk Siswa Kelas 6 SD," Jurnal Sains dan Seni Pomits 2, no. 1 (2013): 28-32.

${ }^{11}$ Marzal Abidin dan Rohati J., "Pengembangan Media Pembelajaran Matematika Interaktif berbasis Android untuk Menumbuhkan Motivasi Belajar Anak Disleksia pada Materi Eksponensial di Kota Jambi," Jurnal Edumatica 4, No. 2 (2014): 66-76. 
Secil". Hasil penelitiannya menyatakan bahwa terjadi peningkatan kemudian stabil dengan presentase skor yang baik. Dengan pembelajaran menggunakan aplikai game secil kesalahan anak dalam membaca pada kemampuan membaca kelompok kata dengan konsonan rangkap "ng" dan "ny" berkurang. ${ }^{12}$

Berdasarkan uraian tersebut maka untuk memberi solusi terhadap permasalahan kemampuan membaca anak disleksia, peneliti juga menggunakan aplikasi pembelajaran yang berjudul Marbel Membaca dengan maksud supaya peserta didik disleksia mendapat peningkatan dalam membacanya. Dari latar belakang tersebut maka peneliti akan mengkaji penelitian tentang " Pengaruh Aplikasi Marbel Membaca Terhadap Kemampuan Membaca Anak Disleksia".

\section{METODE PENELITIAN}

Metode yang digunakan oleh peneliti adalah metode penelitian eksperimen. Adapun desain penelitiannya menggunakan One-Shot Case Study. One-Shot Case Study adalah salah satu bentuk desain penelitian eksperimen yang terdapat perlakuan/treatment kepada suatu kelompok dan selanjutnya diobservasi hasilnya. ${ }^{13}$

Penelitian dilaksanakan pada tanggal 31 Juli 2021 dengan langkah sebelum pelaksanaan yaitu peneliti telah mencari aplikasi yang cocok digunakan dalam pembelajaran membaca anak disleksia dan akhirnya ditemukan aplikasi Marbel Membaca, kemudian peneliti mendownload aplikasi tersebut dan menyiapkan cukup ruang dan sinyal internet supaya saat nanti dalam pelaksanaannya dapat berjalan dengan baik dan lancar. Setelah sukses mendownload maka peneliti mencoba aplikasi Marbel Membaca terlebih dahulu, untuk mengetahui cara memainkan aplikasi marbel membaca dan dapat atau tidak aplikari ini digunakan untuk anak tipe disleksia.

Dalam penerapan metode ini maka langkah-langkah penelitian harus terpenuhi dengan baik. Untuk langkah yang pertama menentukan bahan, alat dan strateginya, seperti menentukan aplikasi pembelajaran yang dapat digunakan oleh anak yang berkebutuhan khusus tipe disleksia. Peneliti akhirnya memilih aplikasi Marbel Membaca. Kemudian untuk strategi yang akan dilakukan oleh peneliti yaitu melakukan pendampingan.

Langkah kedua menentukan tujuan penelitian yaitu anak disleksia dapat hafal abjad a sampai z dengan baik menggunakan bantuan aplikasi Marbel Membaca. Langkah ketiga mempersiapkan kebutuhan peralatan dan sarana yang dibutuhkan, seperti Handphone android dan kuota untuk anak mendownload aplikasi Marbel Membaca di handphone-nya. Untuk media handphone menggunakan milik orang tua dengan pendampingan dari peneliti. Langkah keempat yaitu melakukan uji eksperimen, kegiatannya adalah melakukan pembelajaran menghafal abjad dengan menggunakan aplikasi Marbel Membaca.

12 A Moraza dan Nurhastuti, "Mengurangi Kesalahan Membaca Permulaan pada Anak Disleksia (X) melalui Media Pembelajaran berbasis Aplikasi Game Secil," Juppekhu: Jurnal Penelitian Pendidikan Khusus 9, No. 1 (2021): 35-43.

${ }^{13}$ Sugiyono, Metode Penelitiian Kuantitatif, Kualitatif, Dan R\&D (Bandung: Alfabeta, 2016). 
Untuk teknik pengumpulan datanya peneliti menggunakan 1) Observasi untuk mengetahui tentang perkembangan membaca anak disleksia melalui orang tua, 2) Dokumen berupa nama dan foto catatan menulis anak disleksia, 3) Wawancara dengan bantuan angket yang tujuannya untuk mencari informasi tanggapan anak disleksia setelah menggunakan Aplikasi Marbel Membaca.

Keberhasilan penelitian diukur dengan angket yang direkap menggunakan skala likert untuk mengetahui presentase pengaruh aplikasi Marbel Membaca untuk anak disleksia lalu menggunakan rating scale untuk menafsirkan besar pengaruh aplikasi Marbel Membaca untuk anak disleksia. Dengan rating scale data mentah berupa angka lalu ditafsirkan. ${ }^{14}$ Berikut penafsirannya.

Tabel 1. Kategori Kelayakan Berdasarkan Rating Scale

\begin{tabular}{|c|c|}
\hline Skor dalam persen (\%) & Kategori \\
\hline $0-25 \%$ & Sangat Tidak Suka \\
\hline$>25 \%-50 \%$ & Tidak Suka \\
\hline$>50 \%-75 \%$ & Suka \\
\hline$>75 \%-100 \%$ & Sangat Suka \\
\hline
\end{tabular}

\section{HASIL DAN PEMBAHASAN}

Hasil penelitian mengenai Pengaruh Aplikasi Marbel Membaca Terhadap Kemampuan Membaca Anak Disleksia didapatkan hasil bahwa aplikasi marbel membaca dapat digunakan untuk mengahafal abjad dengan baik, alasannya aplikasi Marbel Membaca menunjukkan satu per satu abjad dengan suara dan apabila ingin mengulangi suara, maka layar handphone dapat disentuh kembali sehingga suara dubbing pada abjad tersebut akan mengulangi bacaannya.

Selain itu, aplikasi Marbel Membaca tidak berjalan secara otomatis, namun aplikasi ini dijalankan secara manual jadi dapat menyesuaikan kebutuhan durasi dalam menghafal abjad satu per satu. Mengingat anak disleksia kesulitan dalam konsentrasi, menghafal, serta membedakan abjad beserta bunyinya.

Selesai menyiapkan bahan alat dan strategi sebelum pelaksanaan, peneliti menentukan tujuan penelitian yaitu anak disleksia dapat menghafal abjad dengan baik menggunakan bantuan aplikasi Marbel Membaca. Tujuan ini dibuat karena anak disleksia sudah naik ke kelas 6 Sekolah Dasar namun belum dapat menghafal abjad dan masih menggunakan bantuan titik-titik untuk menulis jawaban dari soal-soal yang diberikan oleh guru. Tentu saja jika anak disleksia ini tidak mendapatkan pembelajaran yang tepat sesuai dengan kebutuhannya, maka penyakit disleksia ini akan berubah menjadi kelainan yang jika dibiarkan, lama kelamaan akan tambahn sulit untuk menobati dan mengarahkan ke arah anak seumurannya.

Mendekati hari pelaksanaan penelitian, maka peneliti menyiapkan anak disleksia melalui orang tuanya untuk disarankan menyiapkan kebutuhan peralatan dan sarana yang dibutuhkan, seperti Hp android dan kuota untuk mendownload aplikasi Marbel Membaca,

\footnotetext{
${ }^{14}$ Sugiyono.
} 
serta sinyal yang bagus untuk menjalankan aplikasi Marbel Membaca. Peneliti juga mendampingi saat melakukan proses pendownload an supaya aplikasi yang didownload benar dan dapat digunakan dengan baik. Sehingga saat hari penelitian dilaksanakan anak tersebut sudah siap untuk melaksanakanpembelajaran membaca dengan menggunakan aplikasi Marbel Membaca.

Saat waktu penelitian dilakukan, kegiatannya yaitu melakukan uji eksperimen, pembelajaran menghafal abjad dengan menggunakan aplikasi Marbel Membaca. Kegiatannya yaitu membimbing dalam proses belajar anak disleksia kelas 6 Sekolah Dasar. Bentuk bimbingan yang diberikan peneliti yaitu pembelajaran membaca dengan aplikasi marbel dengan metode repetisi (pengulangan secara intensif). Adanya fitur yang menarik seperti desain menu yang menarik serta adanya audio dari aplikasi marbel membuat anak disleksia bersemangat dalam belajar menghafal abjad a-z. Untuk memudahkan proses penghafalan abjad dengan bantuan aplikasi Marbel Membaca, maka langkah selanjutnya yaitu peneliti memberikan angket untuk anak disleksia dengan cara ditanya.

Pertayaannya telah dibuat oleh peneliti sebagai berikut: 1) Apakah kamu senang belajar membaca dengan Marbel Membaca?; 2) Apakah membaca dengan aplikasi Marbel Membaca mudah?; 3) pertanyaannya adalah Apakah kamu mau diajak membaca dengan tingkatan yang berbeda dengan menggunakan aplikasi Marbel Membaca?; 4) Apakah terjadi peningkatan untuk mampu menghafal abjad dengan Aplikasi Marbel Membaca? Berdasakan jawaban-jawaban yang diberikan oleh peneliti, maka peneliti mengelompokkannya dalam skala likert dimana sangat tidak suka: skor 1 , tidak suka: skor 2, ragu-ragu: skor 3, suka: skor 4, dan sangat suka: skor 5 . Setelah didapatkan hasil dari skala likert.

Kemudian hasil dari penelitian ini adalah respon atau tanggapan anak disleksia setelah melakukan pembelajaran dengan Marbel Membaca, ditunjukkan dalam diagram 1 dibawah ini.

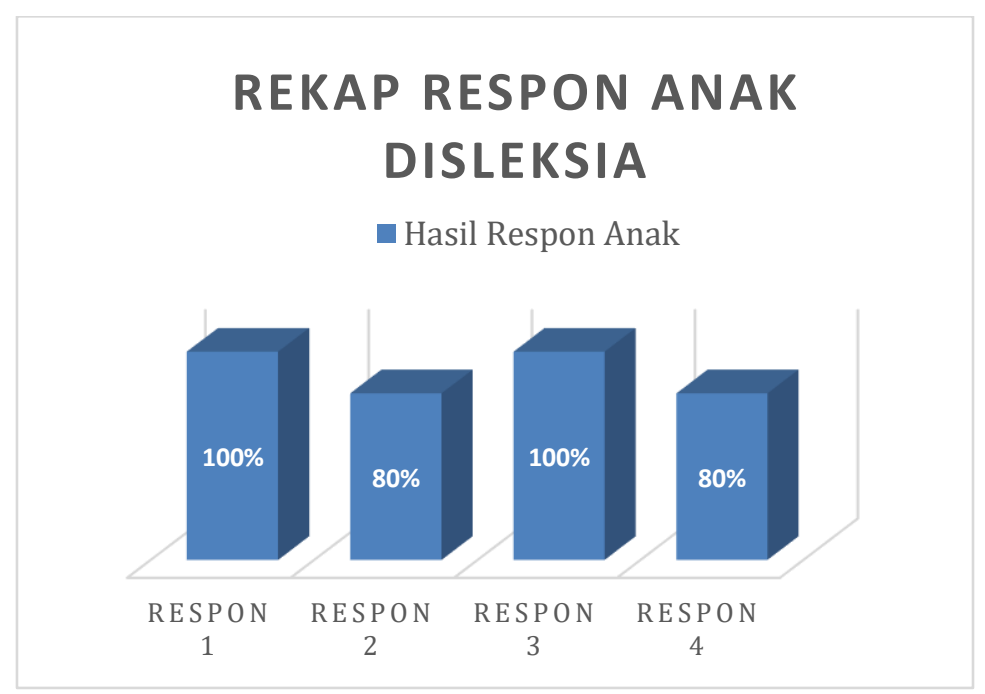

Gambar 1. Rekap Respon Anak Disleksia 
Hasil respon dari anak disleksia dalam diagram batang diatas setelah melakukan pembelajaran dengan menggunakan aplikasi Marbel Membaca, dapat dideskripsikan bahwa respon 1 pertanyaannya adalah: Apakah kamu senang belajar membaca dengan Marbel Membaca? Anak disleksia memilih 100\% dengan kata lain hasilnya sangat suka. Respon 2 pertanyaannya adalah: Apakah membaca dengan aplikasi Marbel Membaca mudah? Anak disleksia memilih $80 \%$ atau suka. Respon 3 pertanyaannya adalah: Apakah kamu mau diajak membaca dengan tingkatan yang berbeda dengan menggunakan aplikasi Marbel Membaca? Anak disleksia memilih 100\% atau dapat ditafsirkan sangat suka. Respon 4 pertanyaannya adalah: Apakah terjadi peningkatan untuk mampu menghafal abjad dengan Aplikasi Marbel Membaca? Anak disleksia memilih 80\% atau dapat ditafsirkan suka jadi terjadi peningkatan.

Berdasarkan perincian hasil respon anak disleksia setelah melakukan pembelajaran menggunakan Aplikasi Marbel Membaca, didapatkan respon positif yaitu prosentase nya 90\% total prosentase hasil respon dari anak disleksia atau dapat ditafsirkan hasilnya masuk kedalam kategori sangat suka. Sehingga ada pengaruh aplikasi marbel membaca terhadap kemampuan membaca anak disleksia.

Hal ini sejalan dengan penelitian yang dilakukan oleh Sabri, Zulmiyetri, \& Damr Tahun 2018 yang menyatakan bahwa frekuensi membaca oleh anak disleksia menggunakan media interaktif terlihat adanya peningkatan. Peningkatan tersebut ditunjukan dengan adanya dari hafalan abjad a-z dan bisa membedakan bentuk huruf tanpa kebolak-balik. ${ }^{15}$ Hal ini juga Didukung juga oleh penelitian yang telah dilakukan oleh Purnomo, Azizah, Hartono, Hartatik, \& Bawono Tahun 2017 yang menyatakan bahwa aplikasi games "two dis" memberikan nuansa bermain dan belajar sibuktikan hasil penilaian pendapat dari respon 16 anak mendapat 100\% atau kategori menarik dan mudah dimainkan. ${ }^{16}$ Dari pernyataan tersebut jelas bahwa aplikasi pembelajaran yang sesuai dengan kebutuhan anak dengan tipe disleksia dapat meningkatkan motivasi, minat dan pemahaman dalam membaca, dengan demikian anak tersebut apabila secara rutin diberi stimulus sesuai dengan kebutuhannya, maka tidak menutup kemungkinan anak disleksia dapat berinteraksi secara normal dalam masyarakat, juga dapat mengikuti ketertinggalan pelajarannya diantara teman-teman seusianya. Karna sejatinya anak disleksia bukanlah anak yang cacata mental atau abnormal, namun hanya terdapat gangguan di syaraf batang otak dimana itu adalah syaraf bahasa.

\section{E. PENUTUP}

\section{Simpulan}

Berdasarkan hasil penelitian pengaruh aplikasi marbel membaca terhadap kemampuan membaca anak disleksia berupa pembelajaran dengan metode eksperimen bersama anak disleksia berbantu aplikasi Marbel Membaca yang telah dilakukan, maka simpulan yang dapat diambil adalah. Berdasarkan rekap respon anak disleksia mendapat

${ }^{15}$ A. Sabri, Zulmiyetri, dan Damri, "Penggunaan Multimedia Interaktif terhadap Kemampuan Membaca Kata Berpola KV-KVK bagi Anak Disleksia,” Jurnal Pendidikan Kebutuhan Khusus 2, no. 2 (2018): 15-18.

${ }^{16}$ A Purnomo et al., "Pengembangan Game untuk Terapi Membaca bagi Anak Disleksia dan Diskalkulia," Jurnal Simetris 8, no. 2 (2017): 497-506. 
90\% atau dikategorikan anak disleksia sangat suka dan terjadi perubahan untuk menghafal serta membaca abjad bagi anak disleksia. Perubahan yang dihasilkan yaitu adanya semangat dan ketertarikan belajar membaca serta anak disleksia bisa lancar mengucapkan abjad a-z tanpa kebolak-balik. Perlu adanya pendampingan secara intensif dan continue untuk lebih meningkatkan kelancaran proses membaca pada anak disleksia. Dengan demikian maka aplikasi Marbel Membaca dapat digunakan atau diterapkan dalam pembelajaran membaca untuk anak disleksia.

\section{Saran}

Saran yang diberikan peneliti adalah sebaiknya penelitian yang telah dilakukan dilanjutkan hingga anak disleksia dapat menulis hingga merangkai kata menjadi sebuah kalimat tanpa dibantu oleh orang lain.

\section{F. DAFTAR PUSTAKA}

Abidin, Marzal, dan Rohati J. "Pengembangan Media Pembelajaran Matematika Interaktif Berbasis Android untuk Menumbuhkan Motivasi Belajar Anak Disleksia pada Materi Eksponensial di Kota Jambi." Jurnal Edumatica 4, No. 2 (2014): 66-76.

Arindino, R. Y, dan N. Ramadhani. "Perancangan Media Pembelajaran Interaktif Matematika untuk Siswa Kelas 6 SD." Jurnal Sains dan Seni Pomits 2, No. 1 (2013): 28-32.

Aulia, R. "Meningkatkan Kemampuan Membaca Pemahaman pada Anak Tunarungu." E-JUPEKhu (Jurnal Ilmiah Pendidikan Khusus) 1, No. 2 (2012): 347-357.

Irdamurni, Kasiyati, Zulmiyetri, and J Taufan. "Meningkatkan Kemampuan Guru pada Pembelajaran Membaca Anak Dislesksia." Jurnal Pendidikan Kebutuhan Khusus 2, No. 2 (2018): 29-40.

Moraza, A, and Nurhastuti. "Mengurangi Kesalahan Membaca Permulaan pada Anak Disleksia (X) melalui Media Pembelajaran Berbasis Aplikasi Game Secil." Juppekhu: Jurnal Penelitian Pendidikan Khusus 9, No. 1 (2021): 35-43.

Purnomo, A, I. N Azizah, R Hartono, Hartatik, dan S. A Bawono. "Pengembangan Game untuk Terapi Membaca bagi Anak Disleksia Dan Diskalkulia." Jurnal Simetris 8, no. 2 (2017): 497506.

Rahaman, Budi, and Haryanto. "Peninkatan Ketrampilan Membaca Permulaan melalui Media Flashcard pada Siswa Kelas 1 SDN Bajayau Tengah 2." Jurnal Prima Edukasia 2, No. 2 (2014): 127-37.

Rofiah, N. H. "Proses Indentifikasi: 'Mengenal Anak Kesulitan Belajar Tipe Disleksia bagi Guru Sekolah Dasar Inklusi'." Jurnal Inklusi 2, No. 1 (2015): 109-124.

Sabri, A., Zulmiyetri, and Damri. "Penggunaan Multimedia Interaktif terhadap Kemampuan Membaca Kata Berpola KV-KVK bagi Anak Disleksia." Jurnal Pendidikan Kebutuhan Khusus 2, No. 2 (2018): 15-18.

Sugiyono. Metode Penelitiian Kuantitatif, Kualitatif, Dan R\&D. Bandung: Alfabeta, 2016. 
204 | 
